luncheons following the degree congregations will long be remembered. It will be difficult for old Clare men to think of the College without Thirkill as mister or tutor, but they may be comforted by the knowledge that he will continue in residence on his retirement.

Sir Eric Ashby

The Fellows of Clare College have announced their intention of electing Sir Eric Ashby into the mastership of the College on the retirement of Sir Henry Thirkill. Sir Eric, who has been vice-chancellor of The Queen's University, Belfast, since 1950, was elected on March 13 into a Fellowship of the College. From the City of London School, Ashby went to the Imperial College of Science and Technology, where he later became a demonstrator in botany and, after two years in America as a Commonwealth Fellow, a lecturer during 1931-35. His next post was reader in the University of Bristol until 1938, when he was appointed professor of botany in the University of Sydney. The sea-trip to Australia with a young family was so turbulent that Ashby swore never to return. Fortunately for the cause of education in Britain, the busy years that followed made him forget his resolve. Searcely was he settled in Sydney when the Second World War made heavy demands upon him. $\mathrm{He}$ was ohairman of the Australian National Research Council, 1940-42, and director of the Scientific Liaison Bureau, 1942-43, having conducted an inquiry for the Prime Minister into the enlistment of scientific resources in 1942. In 1945 he went to Moscow as Counsellor and chargé d'affaires at the Australian legation. His experiences there are recounted in the Penguin book, "Scientist in Russia". In 1946 he left Australia to become Harrison professor of botany and director of the Botanical Laboratories in the University of Manchester, where he remained until he went to Belfast as vice-chancellor. While continuing his interest in botany, Ashby has found time for many other activities, including the administration of research, having been a member of the Advisory Council on Scientific Policy (1950-53), of the Advisory Council on Scientific and Industrial Research since 1954 and chairman of the Scientific Grants Committee since 1955. Above all, he is well known as a writer, and thinker, on educational problems.

\section{Research at Imperial Chemical Industries :}

Mr. R. M. Winter

Mr. R. M. WINTER, who is retiring from the post of research controller of Imperial Chemical Industries, Ltd., after thirty years service with the Company, was born in Scotland in 1896, and emigrated in early childhood to New Zealand, where he received most of his formal education. On graduating B.Sc. in 1916, he volunteered for military service and served with the New Zealand Division in France, where he was wounded. At the end of the War he worked for a time at the Royal College of Science as a research student under Prof. H. Brereton Baker, and on his return to New Zealand was awarded an 1851 Exhibition science research scholarship. After a year's research at the Rothamsted Experimental Station, he joined the staff of the Explosives Research Department at Woolwich Arsenal, where he remained until the end of 1927. He joined Synthetic Ammonia and Nitrates, Ltd. (now the Billingham Division of Imperial Chemical Industries), early in 1928 and was transferred to the General Chemical Division as research manager in 1931. In 1937 he moved to Head Office as chief assistant to Dr. R. E. Slade, who was then research general manager, and was appointed research controller in 1946.

$$
\text { Dr. M. A. T. Rogers }
$$

Dr. M. A. T. Rogers, head of the Academic Relations Department of Imperial Chemical Industries, has been appointed research controller in succession to Mr. R. M. Winter. Dr. Rogers was born at Mill Hill in 1911, and received both the B.Sc. and Ph.D. degrees from University College, London, where he was a Tuffnell Research Scholar and the Ramsey Memorial Medallist for 1933. Dr. Rogers joined the Dyestuffs Division of Imperial Chemical Industries as a chemist in 1934, and served in the Azo Section until 1936, the Textile Auxiliary Section until 1939 and the Exploratory Research Section until 1942. In that year, Dr. Rogers joined the Royal Artillery, and when he returned from his military service he became engaged in research on penicillin with Sir Robert Robinson at the Dyson Perrins Laboratory, Oxford. In 1946, Dr. Rogers joined the Medicinal Research Division, and in 1949 he became head of the Academic Relations Department of the Dyestuffs Division of Imperial Chemical Industries.

\section{Atomic Energy Insurance}

THe second international Atomic Energy Insurance Conference, held in London during February 26-28, under the chairmanship of Mr. H. T. Silversides, issued in a widespread agreement by representatives from fifteen European countries on the broad approach to the insurance of risks arising out of the use of nuclear energy reactor installations. Essential features of pool management agreements were discussed, and it was decided that the material damage risks to be pooled should be the insurance of damage to nuclear installations (defined as nuclear reactors, nuclear power stations, and plant and facilities for producing nuclear energy), including contamination by radioactivity. Third party liability for damage and loss of life or injury arising out of the use of nuclear installations is also to be pooled, and each reactor and third party liability must be comprehensively covered. All the participants in the Conference endorsed the principle that a single insurance policy should be effected by the owner or operator of the reactor, who should also accept all responsibility for radiation liabilities for contractors and suppliers of parts, and undertake to indemnify the contractors and suppliers from any legal liability for radiation risks. The Government of the United Kingdom has already agreed to this approach in fixing an absolute liability at law and requiring insurance to a sum of $£ 5$ million or proof of equivalent liquid assets. A special committee of representatives of Belgium, France, Germany, Holland, Italy, Swoden, Switzerland and the United Kingdom is meeting in April to consider hazards, evaluations and surveys ; the basis of premium rating; and the policy cover to be offered ; while legislative aspects of nuclear insurance will continue to be handled by the Organization for European Economic Co-operation and the European Committee for Insurance.

\section{Industry and Atomic Power}

Av illustrated brochure entitled "Atomic Power Achievements" (chairman's address at the Fiftyseventh Annual General Meeting, London, September 